\title{
PRACTITIONER OF COOPERATIVE LEARNING AS PART OF NOVICE TEACHERS' PROFESSIONAL IDENTITY
}

\author{
Puji Astuti \\ (puji.astuti.ssu@gmail.com) \\ Universitas Negeri Semarang \\ Kampus Sekaran Gunungpati Semarang Indonesia 50229
}

\begin{abstract}
This paper identifies challenges that English as a foreign language (EFL) novice teachers in Indonesia may face in developing a professional identity, which, in this paper, refers to becoming a practitioner of cooperative learning. Cooperative learning is a mandated teaching method both in the 2006 and 2013 Indonesian curriculum, and is under the umbrella of Communicative Language Teaching approach that has been adopted by English instruction in Indonesia since 1980s. This approach stresses interaction between language learners and the use of the target language in this interaction. Drawing on four related theories of development of selves (Wenger's Concepts of Community of Practice, Lave and Wenger's Concepts of Situated Learning: Legitimate Peripheral Participation, Gee's Sociocultural Views of Identity, and Holland, Lachicotte, Skinner, and Cain's Concepts of Identity and Agency in Cultural Worlds), four challenges to the development of the target professional identity are identified: (1) the unavailability of community of cooperative learning practitioners, (2) hegemony vs. identity development, (3) agency in the midst of tensions, and (4) institutional identity vs. professional identity. These interconnected and overlapping challenges suggest novice EFL teachers to possess agency to attain the target identity and suggest teacher education programs to equip their student teachers with knowledge and skills of teacher identity development and agency.
\end{abstract}

Keywords: EFL, cooperative learning, practitioner of cooperative learning, novice teachers, professional identity

DOI: http://dx.doi.org/10.15639/teflinjournal.v27i2/132-152 
This conceptual analysis paper proposes the notion of practitioner of cooperative learning as part of novice teachers' professional identity and discusses challenges that may be faced by these teachers, particularly in the context of English as a foreign language (EFL) instruction in Indonesia, in developing the target identity. Before doing so, with my intent to provide a rationale for why these areas call for our attention, I will first discuss in this section existing studies on teacher identity development and agency in English teacher education programs. Next, key terms - teacher professional identity and cooperative learning - are introduced. I will then talk about the position of cooperative learning in Indonesian curriculum and EFL instruction, especially with regard to the adoption of Communicative Language Teaching (CLT) and how the principles of this approach appear not to be enacted in Indonesian EFL classrooms.

A number of studies have indicated the need for the inclusion of teacher identity development in teacher education. Kanno and Stuart (2011) studied two graduate students in a master's program in Teaching English to Speakers of Other Languages (TESOL) at an American university as they taught their own English as a second language (ESL) classes. Their study demonstrates the intertwined relationship between novice teachers' identity development and their changing classroom practice. Based on their study, Kanno and Stuart argue for the need to include a deeper understanding of teacher identity development in the knowledge base of second language (L2) teacher education. They go on to state that knowledge acquisition is part of this identity development, not the other way around. In other words, the development of L2 teacher identity should be at the center of research and debates on L2 teacher education.

$\mathrm{Xu}$ (2012) conducted a 3-year longitudinal case study of the transformation of the professional identities of four teachers of English to speakers of other languages (ESOL) in China during their first years of teaching in K-12 schools. The study shows that the novices' professional identities changed from the initial imagined identities formed in the pre-service stage to the practiced identities constructed in the novice stage. The aforementioned researchers argue for the need to include a deeper understanding of teacher identity development in the knowledge base of L2 teacher education and suggest that perseverance and agency be instilled in novice teachers' development. In sum, the two studies demonstrate the necessity for teacher education programs to include knowledge on teacher identity development and agency in their curriculum to 
better prepare their graduates for challenges in the early stages and throughout their profession.

Learning that there is a need for the inclusion of identity development and agency in the curriculum of teacher education programs, I am eager to see how these concepts help me to identify possible challenges faced by EFL novice teachers in the attainment of a professional identity, which in this paper refers to becoming a practitioner of cooperative learning. While I am also interested to study how EFL novice teachers in Indonesia develop their expertise in cooperative learning, this paper will focus more on how social interaction and the communities of teachers challenge the attainment of the target identity. It is toward gaining understanding of these challenges and how it would inform the inclusion of knowledge on teacher identity development and agency in teacher education programs that this paper is devoted.

This paper focuses on the identity development of EFL novice teachers in Indonesia as cooperative learning practitioners, positioning it as part of their professional identity. Leuhmann (2008) lends me a definition of teacher professional identity: "being recognized by self or others as a certain kind of teacher" (p. 293). In light of this definition, professional identity in this paper means being recognized by self and others as a kind of EFL teachers who practice cooperative learning. By practitioners, I mean teachers who: (1) understand and master the principles and instructional strategies (techniques) of cooperative learning, (2) implement these techniques in their instruction effectively, i.e., the implementation of cooperative learning that enhances their students' EFL learning, and (3) strive to make this teaching method as a common practice in their EFL teaching community. I limit the scope of the phrase "being recognized by others" to being recognized by other teachers within EFL teaching professional communities.

Kagan and High (2002) describe cooperative learning as a teaching method in which students work in groups and their social interaction in the group is structured to ensure positive interdependence, individual accountability, equal participation, and simultaneous interaction. Cooperative learning has been found beneficial across educational contexts, regardless of age of learners and content-area subjects (Slavin, 1995). It is a teaching method mandated by the Process Standard of Primary and Secondary Education, stipulated as the Decree of the Minister of National Education of the Republic of Indonesia Number 41 Year 2007 for the 2006 curriculum. This Standard mandates teachers to facilitate students' learning in three stages: opening, main, and closing. Cooperative 
learning is mandated as one of the teaching methods to be implemented at the main stage of learning. It reads, "Teachers facilitate students in cooperative and collaborative learning" (Board of National Education Standards, 2007, p. 5). Although the most recent Process Standard (stipulated by the Decree of the Minister of Education and Culture-previously known as the Minister of National Education - number 65 year 2013) does not explicitly mention cooperative learning, it underscores student-centered learning, active learning and learning in groups (Board of National Education Standards, 2013, p. 2). These learning concepts, as references suggest (e.g., Cohen, 1994; Keyser, 2000; Richards, 2002; Sharan, 2002), are some of the underlying concepts of CL. Above all, the Law Number 20 Year 2003 on the Indonesian Education System prescribes active learning to take place in our classrooms. Keeping the Decrees and the Law in mind, hence, it is a legitimate endeavor for teachers in Indonesia to aim at becoming and being recognized by other teachers as practitioners of cooperative learning, and making it part of their professional identity. Moreover, as cooperative learning is a mandated teaching method, supposedly all teachers in Indonesia know and will not be against it when their colleagues make it their educational philosophy and practice.

Indonesia has taken a firm political stance toward English language since 1960 s, i.e. positioning it as a foreign language. It is taught as a subject at schools. Despite curriculum changes, CLT has been one of the approaches to EFL instruction in Indonesia in the past three decades (Lie, 2007) and still remains in place today (Agustien, 2015). This approach to language teaching highlights the importance of student-student interaction in their learning and the use of the target language in this interaction; students learn the language by using it to communicate with their peers (Larsen-Freeman, 2012). Richards (2002) states that cooperative learning is under the umbrella of CLT approach. Literature shows that the use of cooperative learning has a positive effect on ESL/EFL learners' mastery of language skills and components (e.g., Bejarano, 1987; Ghaith, 2003; Liang, 2002; Sachs, Candlin, \& Rose, 2003). These provide affirmation for English teachers in Indonesia to aim at becoming practitioners of cooperative learning and making it part of their professional identity.

As in many contexts of education, where what is mandated is far removed from classroom reality, cooperative learning hardly takes place in classrooms in Indonesia. Zulfikar (2009) noted that teacher-centered instruction and rote learning were prevalent in Indonesian classrooms. Marcellino's study (2008) suggested that ineffective classroom interactions in most EFL classrooms in 
Indonesia were due to the teachers' performance. Most Indonesian EFL teachers tend to faithfully follow textbooks and student work sheets; they barely provide opportunities for students to use the target language and to interact with their peers (Alwasilah, 2012; Lie, 2007; Musthafa, 2009). This reality of EFL instruction affected the achievement of EFL learners in Indonesia. Anderson (2012) reported a survey involving 1.7 million adults from 54 non-English speaking countries, which focused on these adults' English proficiency. The study ranked Indonesia at 27 th, categorizing the country as one of the low English proficiency countries.

Literature suggests that student teachers would usually teach the way they were taught. Keeping this notion in mind, and considering the fact that CL was a mandated teaching method and endorsed by the literature for enhancing EFL learning, as well as the fact that cooperative learning hardly takes place in EFL classrooms in Indonesia, I see the need for EFL teacher education programs to revisit their curriculum. Specifically, cooperative learning needs to be an integral part of Indonesian EFL teacher education's curriculum. However, this paper will not focus on how these programs develop their teacher candidates' identity as cooperative learning practitioner. Different EFL teacher education programs in Indonesia may approach courses of EFL teaching methods differently, and cooperative learning may or may not be present in their teaching method courses. Instead, throughout this paper I position graduates of these programs as novice teachers who understand and master the principles and instructional strategies of cooperative learning. It is because I am more interested to see how EFL novice teachers could develop the target identity in real communities: community of teachers, community of EFL teachers, community of novice teachers, community of novice EFL teachers, and any other available communities. Using theories of development of selves and identity, I hope to uncover challenges that these novices might face in developing themselves as practitioners of cooperative learning.

In the section that follows, I will explore Wenger's (1998) community of practices, Lave and Wenger's (1991) situated learning: legitimate peripheral participation, Gee's (2000-2001) sociocultural views of identity development, and Holland et al.'s (1998) identity and agency in cultural worlds, to provide insights into how EFL novice teachers construct their practitioner of cooperative learning identity. I argue that these novices' trajectory of pursuing this part of their professional identity is full of challenges. The aforementioned theories will shed light on ways that teacher education programs can do to support their 
novice teachers' emerging identities, and inform ways for the incorporation of knowledge of teacher identity development and agency in their curriculum.

\section{CONCEPTS OF IDENTITY DEVELOPMENT AND AGENCY}

This section briefly discusses four concepts of identity development and agency under sociocultural views of the development of selves. Following each of them are the overarching questions that later will guide the discussion in this paper.

\section{Wenger's Concepts of Community of Practice}

Wenger (1998) posits that learning is social participation. Participation, in his view, "refers not just to local events of engagement in certain activities with certain people, but to a more encompassing process of being active participants in the practices of social communities and constructing identities in relation to these communities" (p. 4). Wenger then proposes four components of this learning theory: meaning, practice, community, and identity. Wenger suggests that people need a community to develop their practice. Through this community, people can engage with other community members and acknowledge each other as participants. Through this engagement, people gain experience of their participation and learn from how other people in the community reify their participation. Identity develops because of this participation, reification from others, and this experience and its social interpretations.

Further, Wenger proposes three dimensions of community: mutual engagement, a joint enterprise, and a shared repertoire. Besides experience, he also stresses the importance of a display of competence in one's identity development processes. The following overarching questions are generated from Wenger's concepts of community of practice: 1) What do EFL novice teachers need to do if the community of practitioners of cooperative learning is not available and perhaps not valued?; 2) What to do if the three dimensions of practice: mutual engagement, a joint enterprise, and shared repertoire are hardly present in the available communities (community of teachers, EFL teachers, novice teachers, EFL novice teachers)?; and 3) How will the target identity develops if these novices hardly have opportunities to display their cooperative learning competence in these available communities? 


\section{Lave and Wenger's Concepts of Situated Learning: Legitimate Peripheral Participation}

In simple words, Lave and Wenger's (1991) concept of legitimate peripheral participation (LPP) means learning by doing in particular communities of practice. They posit that LPP is the process by which newcomers become part of a community of practice and a full participant in a sociocultural practice by learning the knowledgeable skills. This concept highlights the importance of community as one of the dimensions of learning (Wenger, 1998). Lave and Wenger (1991) propose LPP as, "a descriptor of engagement in social practice that entails learning as an integral constituent" (p. 35). Implied in this concept is the importance of engagement that involves learning. They warn us, however, that hegemony over resources for learning and alienation from full learning might impede learning processes.

Lave and Wenger (1991) suggest that once people develop the knowledgeable skills in their community of practice, their next calling will be the reproduction and transformation of this community. These tasks are doable if people go through this series of role changing: "from entrance as a newcomer, through becoming an old-timer with respect to newcomers, to a point when those newcomers themselves become old-timers" (p. 56). Yet, going back to the notion of hegemony, Wenger and Lave remind us that there is this reality of conflict between forces that support processes of learning and those that work against them. Forces that work against learning could be in the form of the unavailability of opportunity to talk during the learning processes in the community of practice. In fact, such an opportunity is essential in developing transparency of practice; i.e., people are doing what is accepted by the body of knowledge. The hegemony and outside forces that hinder people's development of identity call for their motivation and agency. Questions to ponder based on Lave and Wenger's LPP are as follows: 1) What do the EFL novice teachers need to do in dealing with hegemony over resources for learning and alienation from full learning?; 2) What do these novices need to do if opportunities to talk are not available?; 3) How should these novices deal with the fact that cooperative learning is not a common practice in their community?; and 4) What should these novices need to do to keep their agency high in their identity development processes? 


\section{Gee's Sociocultural Views of Identity}

Gee (2000-2001) defines institutional identity as a position that is authorized by authorities within an institution. He explains that this identity is not naturally given or can be accomplished by individuals. The "power" that determines this identity, in Gee's view, works through laws, rules, traditions, or principles of various sorts set by the authorities to "author" the position and people with this position "in terms of holding the rights and responsibilities that go with that position" (p. 102).

Another type of identity that Gee proposes and suits the discussion in this paper is affinity identity, that is, "something that one must actively choose to join" (p.105). By joining a group, people can share practices that are specific to every group member's experience. A key to one's growth in this affinity group is their participation. Questions from this theory of identity that relate to the issue being discussed are: 1) How would institutional identity impede the EFL novice teachers' professional identity development?; and 2) How would the available affinity groups help these novices' professional identity development?

\section{Holland et al.'s Concepts of Identity and Agency in Cultural Worlds}

In discussing the idea of identity and agency, Holland, et al. (1998) eloquently state:

Thus persons and, to a lesser extent, groups are caught in the tensions between past histories that have settled in them and the present discourses and images that attract them or somehow impinge upon them. In this continuous self-fashioning, identities are hard-won standpoints that, however dependent upon social support and however vulnerable to change, make at least a modicum of self-direction possible. They are possibilities for mediating agency. (p. 4)

These authors suggest that although community plays a crucial role in people's identity development, people need to have the self-drive, human striving, or agency to face tensions between what has been established by people before them and a new discourse and image that they are trying to embrace in themselves and in their community. In other words, people need agency in their identity development. 
Holland et al. (1998) also posit, "Identities are lived in and through activity and must be conceptualized as they develop in social practice" (p. 5). This notion relates to two of Wenger's (1998) four dimensions of learning: practice and identity. Through practice, people develop their identity. As they develop a particular identity that they are trying to attain, their practice becomes practice with perspective, which could include reflexivity, agency, and change. Holland et al. (1998) say it best:

A person engaged in social life, a person involved in an activity or practice, is presumed to have a perspective. One looks at the world from the angle of what one is trying to do. Persons look at the world from the positions into which they are persistently cast. (p. 44)

Drawing on the above concepts of identity and agency, I have the following questions that relate to the topic under discussion: 1) How do the EFL novice teachers preserve and enact their agency in the midst of tensions between past histories and the new discourses and images?; 2) How do these novices organize their act of practices with perspectives?; and 3) Who would be the recipients of these novices' practice with perspectives? These questions, along with the ones related to the concepts previously discussed, help us to better understand challenges that may be faced by Indonesian EFL novice teachers in attaining their practitioner of cooperative learning identity.

\section{CHALLENGES FACING PRACTITIONERS OF COOPERATIVE LEARNING}

The four theories (community of practice, LPP, sociocultural views of identity, and identity and agency in cultural worlds) discussed in the previous section and the overarching questions generated from them help me to identify four themes concerning the issue being discussed. These themes are: 1) the unavailability of community of practitioners of cooperative learning, 2) hegemony vs. identity development, 3) agency in the midst of tensions, and 4) institutional identity vs. professional identity. These themes also symbolize the challenges that the EFL novice teachers may face in developing their professional identity, where the key component is being a practitioner of cooperative learning. 


\section{The Unavailability of Community of Cooperative Learning Practitioners}

According to Wenger (1998), the connection between identity and practice is very close. He argued that developing a practice requires the formation of a community whose members can engage with one another and thus acknowledge each other as participants. In the case of novice EFL teachers in Indonesia, teacher communities available are the community of Indonesian teachers (Persatuan Guru Republik Indonesia-PGRI) and community of EFL teachers in Indonesia (The Association for the Teaching of English as a Foreign Language in Indonesia-TEFLIN). These are two formal national level teacher communities where the former includes all teachers and the latter embraces only Indonesian EFL teachers.

A smaller scale community available for EFL teachers is Musyawarah Guru Mata Pelajaran (MGMP) Bahasa Inggris (English Teachers Professional Learning Network), consisting of English teachers from some schools within the same district or region. Sumardi's (2010) evaluative study reveals the effectiveness of revitalization of English $M G M P$ as a medium for fostering and developing English teachers' professionalism. Involving 25 teachers, the study follows Kirkpatrick's (1996) model of evaluation, employing observation, questionnaire, and interview as data collection methods. The study indicates that the revitalization program of the English $M G M P$ increased teachers' skills and knowledge of philosophical foundations and theories of English teaching at high school level. However, the program does not yield significant impacts on practical level, specifically on the quality of learning; the teachers still tend to employ conventional models of teaching. The study highlights the importance of a trigger from external supports. For example, supports from school principals, colleagues, and teacher education programs, for teachers to apply in their instruction the knowledge and skills gained from the English $M G M P$.

Based on my observation, what is not available for novice EFL teachers who aim to be practitioners of cooperative learning as part of their professional identity is a community of cooperative learning practitioners. I attended three consecutive TEFLIN conferences and did not hear teachers talking about this community. As discussed earlier, cooperative learning is in fact a mandated teaching method and under the umbrella of Communicative Language Teaching that has governed English instruction in Indonesia for more than three decades. Two online communities of EFL teachers of which I am a member barely discussed this teaching method. I also did Google search to see whether there 
was a community of cooperative learning practitioners within the field of EFL teaching in Indonesia. It yielded no results.

Since the needed community is not yet available, I directed my gaze to the available community for the EFL novice teachers at school level: community of EFL teachers. Participating in this community can enable these novices to get a sense of what constitutes the accepted practices and knowledgeable skills. Knowing and understanding these two are important before the novices can go to the highest level of identity development: reproducing and transforming the community. However, these novices may need to be cautious about their membership in this community. As these novices begin their practice in this community of EFL teachers, after some time they might feel that they are, to some extent, different from the other members in the community. These novices might ask themselves question such as: Why are they not implementing cooperative learning? Don't they know that it is a mandated teaching method? Don't they know that it can promote EFL learners' communicative competence? Later on, and this can be more dangerous, these novices might consider that what their senior colleagues are practicing is the "oughtness" (Hicks, 2004) in the community. The real danger is when these novices follow their senior colleagues' practice and forget the identity they are trying to attain.

Wenger (1998) suggests that practice defines a community through three dimensions: mutual engagement, a joint enterprise, and a shared repertoire. Are there studies that reveal whether these three dimensions exist in school-level community of EFL teachers? I have not found such studies, especially those carried out in Indonesian contexts. However, studies showing the prevalence of teacher-dominated learning in Indonesian EFL classrooms (see Alwasilah, 2012, 2013; Intansari, 2010) indicate that perhaps only a few Indonesian EFL learners learn through cooperative learning. These studies also made me assume that the three dimensions of community proposed by Wenger are not present in the available community for the novice EFL teachers, i.e., the communities of EFL teachers at schools. The absence of these three dimensions of community of practice can hamper these novices' development of the target professional identity: cooperative learning practitioner. Challenges are ahead of them. They might ask themselves questions, such as: Who will I turn to when I have problems in implementing cooperative learning? How will I learn from others' practice of cooperative learning? How will I share best practices of cooperative learning? Referring to Wenger's (1998) social theory of learning, identity is developed through practice. Membership in a community of practice 
is thus imperative for people to make meaning of their practice and what they learn. Making meaning through practice will lead to identity development. The novice EFL teachers may find it hard to develop the target identity because of the absence of such practice, such as having discussions on cooperative learning and making meanings of it.

\section{Hegemony vs. Identity Development}

Lave and Wenger (1991) suggest that changing locations of practice and getting others' perspectives are important for identity development. These can be achieved by attending to a wider context of community. In the case of the novice EFL teachers, it can mean attending seminars, conferences, or professional development programs in which they can: 1) meet other practitioners of cooperative learning who might face the same struggles, 2) listen to presentations that might affirm their practice, 3) have opportunities to talk about their practice, and/or 4) get people enthusiastic to learn about this mandated teaching method. Such activities will be beneficial for the development for the target identity. However, in most cases, opportunities to attend seminars, conferences, or professional learning programs are given first to more experienced or senior teachers. This is an example of hegemony over learning resources and opportunity to learn. According to Apple (2004), hegemony means the controlled meanings, practices, values, and actions that might not be visible but continue to exist and that can be found in routine practices. Hegemony is present in schools and communities of teachers because authority or power is there. Therefore, the absence of the three dimensions of community of practice (mutual engagement, a joint enterprise, and a shared repertoire) in the available communities of EFL teachers, which may make novice teachers not have the opportunity to display their competence before their colleagues, can be due to the presence of this hegemonic system.

Outside their school, the novice EFL teachers might have the opportunity to talk about their practice, e.g. in seminars or conferences. However, if they strive to make cooperative learning a common practice in their schools, what is more important is having a chance to display their competence (mastery of cooperative learning) before their colleagues. Getting a chance to display their competence might not be easy for them as novices in the community. At least two identities are at play here: newcomers and practitioners of cooperative learning (the latter being an identity that the novices are trying to develop). 
Therefore, on the one hand these novices are newcomers who need to listen to and learn from their senior colleagues. On the other hand, they feel the urge of displaying their mastery of cooperative learning, not only in their own classrooms but also before other people in the community.

On dilemmas of multiple identities, Holland (2003) concludes, "Dilemmas of orchestrating multiple identities are ignited by and deeply shaped in local practice. These dilemmas become significant if, and only when, improvised resolutions of them prove unintelligible or otherwise unaccepted either socially or on intimate terrain" (p. 47). With regard to the novice EFL teachers' dilemmas of having two identities, Holland's conclusion suggests that local practice contributes to the growth of the dilemma and becomes apparent if what they do is socially unacceptable. For example, during the implementation of a cooperative learning technique, students might become a little loud. This may disturb classes next door. It can happen especially if the students are new to cooperative learning. If these novice teachers explain to the their senior colleague about what they are doing and its benefits, this could be something that is not socially accepted in Indonesian contexts especially if these novices sound like they are lecturing or preaching.

Ways to confront this dilemma is portrayed in Carbaugh's (1996) phrase, "decision making as social drama" (p. 159). Inspired by Victor Turner's and Goffman's concept, Carbaugh explains the phrase this way, "Some processes of decision making, and some conflicts among social identities, begin with some sense of rupture, or a breach, or a violation" (pp. 158-159). Either continuing their practice of cooperative learning or spreading the method through word of mouth, these novices might feel a sense of rupturing, breaching, or violating the norms in their community. A study conducted by Cohen and Tellez (1994) confirmed Carbaugh's portrayal (1996) of decision making. They found that high implementers of cooperative learning viewed rules and regulations of their schools as more confining, and their willingness to try new instructional strategies may be contributed by their perception of themselves as rebels in the school culture.

Being violators of the norm, the novice EFL teachers might get comments behind their back from the senior teachers, such as: Why do these novices bother doing it? What is wrong with our practice? Well, they are new and too energized. These novices need to understand that a feeling of violating the norm is inevitable and should not stop them in achieving the target identity. 


\section{Agency in the Midst of Tensions}

The following excerpt exemplifies tensions that a novice English teacher faces in her early teaching career:

Conversely, Toni felt supported by her principal, but ignored by her mentor and fellow English teachers. While her first year started off positively, she soon learnt that the departmental culture was not conducive for collaboration or mentoring. Throughout her time at the school, Toni described her departmental colleagues as cold and her theory was only reinforced by the other faculty members. Whereas she wanted professional collaboration and the sharing of teaching resources and activities, things she had in her teacher education program, others were content or remain in their rooms and maintain their autonomy. (Scherff, 2008, p. 1328)

Toni experiences tension in herself between what she sees as beneficial (collaboration, mentoring, and sharing of teaching sources and activities - things she learned in her teacher education program) and the reality, i.e. what has been established and become departmental culture (cold, content, and showing autonomy colleagues). Referring to Wenger's (1998) dimensions of a community of practice, i.e. mutual engagement, a joint enterprise, and a shared repertoire, we can say that these dimensions are not present in Toni's department.

Novice EFL teachers in Indonesia most likely face a similar situation that can challenge the attainment of the target identity. How will these teachers be recognized by other teachers in the community as practitioners of cooperative learning if collaboration, mentoring, and sharing of teaching resources and activities are not happening? How to navigate these "recognition works" (Leuhmann, 2007, p. 14)? How will these novices transform and reproduce the community, making it a community of teachers who value cooperative learning as an educational philosophy and practice in the community, if the community does not value cooperation among its members? These novices need to carry out practice with perspectives that come from themselves (agentic). In discussing agency in identity development, Holland, et al. (1998) state:

Persons develop more or less conscious conceptions of themselves as actors in socially and culturally constructed worlds, and these senses of themselves, these identities, to the degree that they are conscious and objectified, permit these persons, through the kinds of semiotic mediation described by Vygotsky, at least a modicum of agency or control over their own behavior. (p. 40) 
The above quote suggests that novice teachers like Toni need to keep in mind that in attaining a target identity, they are an actor in their community. Because they are an actor, what they practice is within the role and perspectives of this actor. It indeed takes initiative, courage, and perseverance to take action to improve (Xu, 2012). If Toni and EFL novice teachers in Indonesia had these traits or agency in them, changes would likely take place. Collaboration, mentoring, and sharing would happen in Toni's department. Cooperative learning would likely be a common practice in Indonesian EFL classrooms.

\section{Institutional Identity vs. Professional Identity}

Referring to Gee's (2000-2001) notion of institutional identity, a law is one of the forms of authorization. It authors people's position, including their rights and responsibilities. The Law Number 14 Year 2005 on Teacher and Lecturer defines teachers as "Professional educator whose main jobs are educating, teaching, guiding, directing, training, assessing, and evaluating learners in early childhood education, formal education, primary education, and secondary education" (p. 2). Regarding teachers' responsibilities, the Law states that they include: lesson planning, carrying out quality learning, assessing and evaluating learning outcome, improving and developing academic qualification and competence sustainably that is in line with the development of knowledge, technology, and art. Teaching profession as an institutional identity in Indonesian contexts, therefore, constitutes doing teaching jobs and bearing the responsibilities as mandated by the Law. While the definition does not suggest teacher-learning throughout teaching profession, the aforementioned responsibilities suggest teachers to improve their competence. How do Indonesian EFL teachers perform their institutional identity?

Alwasilah's (2012) study on aspects of professionalism of 200 middle school EFL teachers in Jakarta and West Java showed that instructional technology was the weakest area of EFL teaching followed by curriculum implementation and methods of teaching. While the number of teachers involved in the study was small, as there are approximately 130,000 EFL teachers in Indonesia, the study suggests that institutional identity does not guarantee one's professionalism. According to Gee (2000-2001), institutional identity is not something that people could accomplish by themselves. He highlights authority as the source of an institutional identity. This authority makes the institutional 
identity available and thus, ideally, should let people either to take (and help them achieve it) or challenge the identity.

The Law Number 14 Year 2005 on Teachers and Lecturers details 11 rights of teachers. Three of these rights, which correlate to the idea of teacher professional identity discussed in this paper, are: (1) the opportunity to develop their competence, (2) the opportunity to develop and improve their academic qualification and competence, and/or (3) training and professional learning in the field. If these are some of the rights of Indonesian teachers, have they received them? The answer to this question is worth researching. Undeniably, it is the responsibility of the authority to provide and make sure that the teachers receive their rights.

Gee's (2000-2001) concept of identity lends perspectives of why teaching method is one of the weakest areas of EFL teaching in Indonesia; they are: access, networking, and experience. EFL teachers in Indonesia might not have: "access to specific networks of people and information spread across the country and the world and to specific experiences connected to these networks" ( $p$. 121). Again, whose responsibility is it to make sure that teachers have these three? It is the authority.

The notion of practitioner of cooperative learning as part of Indonesian EFL teacher professional identity that I propose in this paper could serve as a counter discourse to institutional identity. With that said, I do not mean that institutional identity needs to go away. This is not possible. What I mean is that, since EFL teachers in Indonesia have issues in their teaching method, why not impose a counter identity, i.e. practitioner of cooperative learning as part of EFL teacher professional identity? It is because the institutional identity given and maintained by authority does not always guarantee one's professionalism. In a world where access, networking, and experience appear not to be present, Gee (2000-2001) suggests the formation of new identities that "reinvigorate the local and empower the "locals" [original emphasis] through new forms of discourse and dialogue - forms that remain aware, however, of the fact that in our world, the global has utterly "infected" [original emphasis] the local" (p. 121). In other words, a new identity that Gee proposes is for reviving a community of practices. Setting cooperative learning practitioner as part of teacher professional identity is also intended to revive a community of practice important for teachers' professionalism. 


\section{CONCLUSIONS AND SUGGESTIONS}

As demonstrated in the previous sections, the challenges that are ahead of EFL novice teachers who aim at becoming practitioners of cooperative learning as part of their professional identity are somewhat interconnected and overlapping. Because the community of practitioners of cooperative learning may not be available, EFL novice teachers need to make use of the available community around them, e.g., the community of EFL teachers in their school. This community may not be a supportive community of practice because of the incomplete presence of mutual engagement, a joint enterprise, and a shared repertoire (Wenger, 1998). Hegemonic system might also be prevalent in this community. As hegemony is usually invisible, these novice teachers might not be aware of it and regard the world they live in as normal. In fact, hegemonic system might hamper the attainment of the identity development. Hence, what they need in a community like this is their agency, i.e. their striving to change what is not normal, and later reproduce or transform this existing community into a community of practice (i.e., cooperative learning is practiced by its members and together they develop a better understanding of this practice to better facilitate students' learning).

All in all, I propose a number of suggestions for the betterment of EFL teacher education programs, specifically on how they equip their teacher candidates with knowledge and skills of professional identity development and how these programs provide support for novice teachers' emerging identities. First, teacher education programs need to provide links to professional communities that are supportive of novice teachers' identity development. Perhaps, these programs could collaborate with TEFLIN to hold events such as "TEFLIN goes to campus" through which teacher candidates learn, for example, how the association provides professional development programs for its

members. Second, teacher education programs need to consider having a course on teacher identity development and agency, or address these issues in the existing English language teaching courses, to equip their candidates with knowledge and skills so that they could grow and succeed in their early stages of and throughout their professional life. In addition, by having knowledge and skills of teacher identity development and agency, teacher candidates would see the value of community of practice for themselves as well as for practicing teachers. Third, Holland and Lachicotte (2007) state, "identities are of key importance of social change" (p. 135). This proposal of practitioner of coopera- 
tive learning as part of teacher professional identity is an effort to bring about betterment in two arenas: EFL instruction and teachers' teaching performance. Social change is never an individual effort; it has always been a collective effort. Surely it will not be a too-high aim for EFL novice teachers as long as they are not alone.

\section{REFERENCES}

Agustien, H. I. R. (2015). By definition semua ELT yg bertujuan mengembangkan komunikasi menggunakan CLT [By definition, all ELT that aim at developing communication (communicative competence) use CLT]. [Facebook comment]. Retrieved from https://www.facebook.com/groups/ $626766864032969 /$ search/?query $=$ communicative

Alwasilah, A. C. (2012, May 19). Redesigning the curriculum for English teachers. The Jakarta Post. Retrieved from http://www.thejakartapost. com/news/2012/05/19/redesigning-curriculum-english-teachers.html

Alwasilah, A. C. (2013, September 21). Improving teacher training colleges. The Jakarta Post. Retrieved from http://www.thejakartapost.com/ news/2013/09/21/improving-teacher-training-colleges.html

Anderson, C. (2012, October 2008). Low English levels can hurt countries' progress. The New York Times. Retrieved from http://www.nytimes.com/ 2012/10/29/world/europe/29iht-educbriefs29.html?_r=0

Apple, M. (2004). Ideology and curriculum ( ${ }^{\text {rd }}$ ed.). New York: RoutledgeFalmer.

Bejarano, Y. (1987). A cooperative small-group methodology in the language classroom. TESOL Quarterly, 21(3), 483-504.

Board of National Education Standards. (2007). The Decree of The Minister of National Education of the Republic of Indonesia Number 41 Year 2007 on the Process Standard for Primary and Secondary Education. Jakarta: BNSP.

Board of National Education Standards. (2013). The Decree of The Minister of Education and Culture of the Republic of Indonesia Number 65 Year 2013 
on the Process Standard for Primary and Secondary Education. Jakarta: BNSP.

Carbaugh, D. (1996). Situating selves: The communication of social identities in American scenes. Albany, NY: SUNY Press.

Cohen, E. G. (1994). Restructuring the classroom: Conditions for productive small groups. Review of Educational Research, 64(1), 1-35.

Cohen, M., \& Tellez, K. (1994, April). Variables affecting the teacher implementation of cooperative learning methods in ESL and bilingual classrooms. Paper presented at the $75^{\text {th }}$ Annual Meeting of the American Educational Research Association, New Orleans, LA.

Gee, J. (2000-2001). Identity as an analytic lens for research in education. Review of Research in Education, 25, 99-125.

Ghaith, G. (2003). Effects of the learning together model of cooperative learning on English as a foreign language reading achievement, academic selfesteem, and feelings of school alienation. Bilingual Research Journal, 27(3), 451-474.

Government of Indonesia. (2003). Law Number 20 Year 2003 on the Indonesian Education System.

Government of Indonesia. (2005). Law Number 14 Year 2005 on Teacher and Lecturer.

Hicks, D. (2004). Growing up girl in working-poor America: Textures of language, poverty, and place. Ethos, 32(2), 214-232.

Holland, D. (2003). Multiple identities in practice: On the dilemmas of being a hunter and an environmentalist in the USA. Focaal: European Journal of Anthropology, 42, 31-49.

Holland, D., \& Lachicotte, W. (2007). Vygotsky, Mead, and the new sociocultural studies of identity. In H. Daniels, M. Cole, \& J. V. Wertsch (Eds.), The Cambridge companion to Vygotsky (pp. 101-135). New York: Cambridge.

Holland, D., Lachicotte, W., Skinner, D., \& Cain, C. (1998). Identity and agency in cultural worlds. Cambridge, MA: Harvard University Press. 
Intansari M., R. (2010). Implemented curriculum at a school level: A surveybased case study in junior high schools in Sukabumi. Paper presented at the $57^{\text {th }}$ TEFLIN International Conference, Indonesia University of Education, Bandung, Central Java, Indonesia.

Kagan, S., \& High, J. (2002). Kagan structures for English language learners. ESL Magazine. Retrieved from http://www.kaganonline.com/free_articles/ dr_spencer_kagan/356/ESL-Magazine-Kagan-Structures-for-EnglishLanguage-Learners

Kanno, Y., \& Stuart, C. (2011). Learning to become a second language teacher: Identities-in-practice. The Modern Language Journal, 95(2), 236-252.

Keyser, M. W. (2000). Active learning and cooperative learning: Understanding the difference and using both styles effectively. Research Strategies, 17(1), 35-44.

Kirkpatrick, D. (1996). Evaluating training programs. San Fransisco, CA: Berrett-Koehler Publisher.

Larsen-Freeman, D. (2012). From unity to diversity: Twenty-five years of language-teaching methodology. English Teaching Forum, 50(2), 28-38.

Lave, J., \& Wenger, E. (1991). Situated learning: Legitimate peripheral participation. New York, NY: Cambridge University Press.

Leuhmann, A. (2007). Identity development as a lens to science teacher preparation. Science Education, 91(5), 822-839.

Leuhmann, A. (2008). Using blogging in support of teacher professional identity development: A case study. Journal of the Learning Sciences, 17(3), 287-337.

Liang, T. (2002). Implementing cooperative learning in EFL teaching: Process and effects (Unpublished master's thesis). National Taiwan Normal University, Taipei, Taiwan.

Lie, A. (2007). Education policy and EFL curriculum in Indonesia: Between the commitment to competence and the quest for higher score. TEFLIN Journal, 18(1), 1-14. 
Marcellino, M. (2008). English language teaching in Indonesia: A continuous challenge in education and cultural diversity. TEFLIN Journal, 19(1), 5769.

Musthafa, B. (2009). English teaching in Indonesia: Status, issues, and challenges. Retrieved from http://www.oocities.org/upis3/bm/englishteaching-in-indonesia.htm

Richards, J. C. (2002). 30 years of TEFL/TESL: A personal reflection. RELC Journal, 33(1), 1-35.

Sachs, G., Candlin, C., \& Rose, K. (2003). Developing cooperative learning in the EFL/ESL secondary classroom. RELC Journal, 34(3), 338-369.

Scherff, L. (2008). Disavowed: The stories of two novice teachers. Teaching and Teacher Education, 24(5), 1317-1332.

Sharan, S. (2002). Differentiating methods of cooperative learning in research and practice. Asia Pacific Journal of Education, 22(1), 106-116.

Slavin, R. E. (1995). Cooperative learning: Theory, research, and practice. Boston, MA: Allyn and Bacon.

Sumardi. (2010). Efektivitas program revitalisasi MGMP Bahasa Inggris sebagai media pembinaan profesionalisme guru [The effectiveness of MGMP revitalization program as a medium of teacher professional development]. TAJDIDUKASI, 2(2), 1-17.

Wenger, E. (1998). Communities of practice: Learning, meaning and identity. New York, NY: Cambridge University Press.

$\mathrm{Xu}, \mathrm{H}$. (2012). Imagined community falling apart: A case study on the transformation of professional identities of novice ESOL teachers in China. TESOL Quarterly, 46(3), 568-578.

Zulfikar, T. (2009). The making of Indonesian education: An overview on empowering Indonesian teachers. Journal of Indonesian Social Sciences and Humanities, 2, 13-39. 